\title{
Optimization of the Extraction and Nutritional Value of Tiger Nut Milk by Sequential Design Strategy
}

\author{
Jonas Costa Neto (Corresponding author) \\ Dept. of Biochemical Engineering, Universidade Federal do Rio de Janeiro \\ 149, Av. Athos da Silveira Ramos, Rio de Janeiro, Brazil \\ Tel: 55-21-96976-0160Ｅ-mail: jonasneto@ifma.edu.br
}

Priscilla Amaral

Dept. of Biochemical Engineering, Universidade Federal do Rio de Janeiro 149, Av. Athos da Silveira Ramos, Rio de Janeiro, Brazil

Tel: 55-21-97915-5533Ｅ-mail: pffamaral@gmail.com

Maria Rocha Leão

Dept. of Biochemical Engineering, Universidade Federal do Rio de Janeiro

149, Av. Athos da Silveira Ramos, Rio de Janeiro, Brazil

Tel: 55-21-98162-3414Ｅ-mail:mhrl@eq.ufrj.br

\begin{abstract}
Taísa Gomes
Dept. of Food Technology, Universidade Federal do Maranhão

Av. Curios, Maracanã, São Luis, Brazil

Tel: 55-21-96521-0280Ｅ-mail: taisalisboa@ifma.edu.br
\end{abstract}

\begin{abstract}
Gizele Sant'Ana
Dept. of Biochemical process technology, Universidade Estadual do Rio de Janeiro

R. São Francisco Xavier, - Maracanã, Rio de Janeiro, Brazil

Tel: 55-21-98672-1613Ｅ-mail: gizelecf@yahoo.com.br
\end{abstract}


Received: April 19, 2017 Accepted: May 10, 2017 Published: May 11, 2017

doi:10.5296/jfs.v6i1.11087

URL: https://doi.org/10.5296/jfs.v6i1.11087

\begin{abstract}
Sequential experimental design strategy was applied in order to investigate the best conditions for tiger nut milk extraction process taking into account performance and physicochemical features, simultaneously. Protein, lipid, starch, calcium and total sugar composition were considered for this optimization. The tested factors were: sodium metabisulphite concentration $\left(\mathrm{X}_{1}\right)$, soaking time $\left(\mathrm{X}_{2}\right)$, soaking temperature $\left(\mathrm{X}_{3}\right)$ and water proportion $\left(\mathrm{X}_{4}\right)$. From the $2^{4-1}$ fractional factorial design all independent variables were found to be statistically significant $(\mathrm{p}<0.1)$ and $\mathrm{X}_{1}, \mathrm{X}_{2}$ and $\mathrm{X}_{3}$ were chosen for the central composite design as water proportion was already in the minimum value. The best operational conditions, obtained by desirability function, were: $8 \mathrm{~h}$ of soaking time, $22^{\circ} \mathrm{C}$ for soaking temperature, $0.20 \%(\mathrm{w} / \mathrm{v})$ of sodium metabisulphite and 1:1 tuber $(\mathrm{g})$ : water $(\mathrm{ml})$ proportion. In those conditions a $78 \%$ yield was obtained for a tiger nut milk with $2.60 \%$ protein, $3.7 \%$ total sugar and $8.72 \%$ starch. The high yield obtained and the great nutritional value shows that this milk has a great potential for application in the food industry.
\end{abstract}

Keywords: Tiger nut milk, Soaking, Central composite design, Extraction, Nutritional value

\title{
1. Introduction
}

Tiger nut, chufa or yellow nut sedge (Cyperus esculentus) produces tubers with a yellowish nucleus surrounded by a fibrous sheath of brown color. The tubers are sweet to the palate, with excellent levels of nutrients. (Pascual et al., 2000; Shaker et al., 2009). Among the European countries, Spain stood out mainly in Valencia region for the appreciation and use of the vegetable tubers to develop a non-alcoholic refreshing drink, currently known as "Horchata of Chufa" (Salem et al., 2005). Today, the tiger nut is grown in Northeastern Nigeria, Niger, Mali, Senegal, Ghana and Togo, where it is consumed in natura as a complementary food (Sanchez-Zapatta et al., 2012).

In Brazil, the state of Maranhão has distinguished weather conditions (tropical) to develop the cultivation of this tubercle. The cultivation takes place in some cities in the interior of the state, as Morros, Barra do Corda, Codó, Barreirinhas, Tutóia and Icatú, and it is consumed in natura as a complementary food and used as medicinal plant by the local populations (Oliveira et al., 2006).

The liquid extract obtained from these tubers is called tiger nut milk. This beverage contributes to cholesterol and triglycerides levels reduction, as it decreases low density lipoprotein cholesterol (LDL-C) and increases high density lipoprotein-cholesterol (HDL-C), due to the presence of oleic acid and satisfactory amount of vitamin E (Sanchez-Zapatta et al., 2012 ).

In addition, tiger nut milk has very low sugar concentrations and als appropriate for celiac people (it has no gluten) and those with lactose intolerance. (Corrales et al., 2012).

The production of this milky beverage requires soaking the tiger nut tubers in water for, 


\section{MInstitute Macrothink $_{\text {Int }}$}

approximately, $8 \mathrm{~h}$. Then the soaked tubers are grinded to form a mass which is pressed for the fluid extraction. As this fluid is rich in starch it cannot be heated above $72^{\circ}$, because of gelatinization process that alters the organoleptic properties of this product. Consequently, microorganism control processes that are based on the use of high temperatures cannot be used, causing a limitation for this beverage because its shelf life is short (Cortés et al., 2005; Ejoh et al., 2006; Corrales et al., 2012). Moreover, a standard production protocol in industrial scale needs to be established for a commercial valorization of this product (Asante et al., 2014).

Currently, mathematical models are being developed as means of prediction and optimization of the production process of tiger nut milk, which is primarily based on the soaking process (Krokida et al., 2003; Djomdi et al., 2007), including the use of response surface methodology (Asante et al., 2014). However, none of them have taken into consideration the nutritional characteristics simultaneously to extraction efficiency.

Therefore, we aimed to investigate the improvement of tiger nut milk production process by means of sequential design strategy that is, using a $2^{\mathrm{k}-\mathrm{p}}$ fractional factorial design followed by central composite design. In this study soaking temperature, soaking time, water proportion and sodium metabisulphite concentration were considered to obtain the best conditions for the extraction yield and nutrient values (protein, starch, total sugar, calcium and lipid) of the milk produced, aiming its production at industrial scale.

\section{Materials and Methods}

\subsection{Source and Preparation of Raw Materials}

Tiger nut (Cyperus esculentus) with 0.5 to $1.0 \mathrm{~cm}$ diameter were obtained in the city of Morros, east of the State capital of Maranhão. The tuber was sanitized with $10 \%$ sodium hypochlorite solution $(\mathrm{v} / \mathrm{v})$ and then stored in a freezer $\left(-4^{\circ} \mathrm{C}\right)$.

\subsection{Production of Tiger Nut Milk}

For the milk production, $40 \mathrm{~g}$ tiger nut were suspended in $100 \mathrm{ml}$ of a sodium metabisulphite solution (Sigma-Aldrich CO., MO, USA). This suspension was incubated by $9 \mathrm{~h}$ in a water bath at $25{ }^{\circ} \mathrm{C}$ (Quimis, Brazil) without stirring (soaking step). After saturation, tiger nut were washed with distilled water and then deionized water was added in order to perform the grinding on industrial blender (Fak metalurgica, Brazil, $800 \mathrm{~W}$ ). Sodium metabisulphite concentration, soaking time and temperature and tuber $(\mathrm{g})$ : water $(\mathrm{ml})$ proportion were stabilished in the experimental designs. The solid material was removed from the milk by a sieve of $0.2 \mathrm{~mm}$ of aperture.

The milk was recuperated and weighed for the determination of extraction yield, expressed as percentage of milk obtained from tubers (dry weight basis). (Djomdi et al., 2007).

\subsection{Optimization of Tiger Nut Milk Extraction}

\subsubsection{Fractional Factorial Design}

A fractional factorial design (Ghaedi et al., 2015) was used to evaluate the significant factors influencing the milk production. Four parameters (sodium metabisulphite concentration (\%), soak time (h) water proportion and soaking temperature $\left({ }^{\circ} \mathrm{C}\right)$ ) were included in this study to determine the most significant input factors for the milk production by a two level fraction factorial design $\left(2^{4-1}\right)$ with three central points. The response variables were: extraction yield, 
protein, calcium, lipids and starch concentrations. Table 1 shows the values representing the levels for each parameter studied.

Table 1. Values of coded levels and real values used in the fractional factorial design for 11 runs

\begin{tabular}{llll}
\hline Factors & \multicolumn{2}{l}{ Levels } & \\
& -1 & 0 & +1 \\
\hline Sodium metabisulphite $\left(\mathrm{X}_{1}\right)(\% \mathrm{w} / \mathrm{v})$ & 0.025 & 0.075 & 0.125 \\
Soaking time $\left(\mathrm{X}_{2}\right)(\mathrm{h})$ & 8 & 19 & 30 \\
Soaking temperature $\left(\mathrm{X}_{3}\right)\left({ }^{\circ} \mathrm{C}\right)$ & 25 & 35 & 55 \\
Water proportion $\left(\mathrm{X}_{4}\right)(\mathrm{w} / \mathrm{v})$ & $1: 1$ & $1: 3$ & $1: 5$ \\
\hline
\end{tabular}

It is noteworthy that the temperature interval ranged between 25 and $55{ }^{\circ} \mathrm{C}$. The higher temperature was set up inferior to $60^{\circ} \mathrm{C}$ since higher temperatures cause starch gelatinization (Cortés et al., 2004; Djomdi et al., 2007; Ejoh et al., 2006).

\subsubsection{Central Composite Design (CCD)}

A central composite design (CCD) was defined with the results of the fractional factorial design. The parameters set and used as independent variables were: sodium metabisulphite $\left(\mathrm{X}_{1}\right)$, soaking time $\left(\mathrm{X}_{2}\right)$ and soaking temperature $\left(\mathrm{X}_{3}\right)$ as shown in Table 2; whose values represent the limits for each parameter studied. The response variables used for selection of the best conditions were protein, starch and total sugar concentrations and yield.

Table 2. Factors and levels for the central composite design for 17 runs.

\begin{tabular}{lllllc}
\hline \multirow{2}{*}{ Factors } & \multicolumn{2}{c}{ Levels } & \multicolumn{3}{c}{ Star point $(\alpha=1,68)$} \\
\cline { 2 - 6 } & -1 & 0 & +1 & $-\alpha$ & $+\alpha$ \\
\hline Sodium metabisulphite $\left(\mathrm{X}_{1}\right)(\% \mathrm{w} / \mathrm{v})$ & 0.075 & 0.18 & 0.30 & 0.05 & 0.37 \\
Soaking time $\left(\mathrm{X}_{2}\right)(\mathrm{h})$ & 4 & 6 & 8 & 3.00 & 9.00 \\
Soaking temperature $\left(\mathrm{X}_{3}\right)\left({ }^{\circ} \mathrm{C}\right)$ & 25 & 30 & 35 & 21.6 & 38.4 \\
\hline
\end{tabular}

\subsubsection{Desirability Function (DF)}

Desirability function (DF) is an approach proposed by Derringer and Suich (1980) for simultaneous response optimization where individual goals are combined into a function to find the local solutions. This function $\left(d f_{i}\right)$ is based on a numerical range of 0 - 1 with 1 and 0 meaning the maximum and minimum desirability, according to Derringer and Suich equation as follow (Ghaedi et al., 2015) 


\section{Macrothink}

$(d / f)=(U-\alpha)^{\mathrm{wi}}, \alpha \leq \mathrm{U} \leq \beta$

$$
(\beta-\alpha)
$$

$\left(d f_{i}\right)=1, U>\beta$

$\left(d f_{i}\right)=1, \mathrm{U}<\alpha$

In $\mathrm{Eq}$ (1) $\alpha$ and $\beta$ are the lower and higher values, respectively (obtained from $\mathbf{i}$ response) and wi is the importance level. The scores of individual desirability to the levels required for each dependent variable are combined with the DF function through its geometric mean for all different values $\left(d f_{i}\right)$.

$\mathrm{DF}=\left[d f t^{\mathrm{v1}}{ }_{1} \mathrm{x} d f t^{\mathrm{v} 2}{ }_{2} \ldots d f_{\mathrm{n}}\right]^{1 / \mathrm{n}}, 0 \leq v t \leq 1(\mathrm{i}=1,2,3, \ldots, \mathrm{n})$

$\sum_{i-1}^{m} w b=1$

Where $d f_{i}$ indicates the desirability of response $\mathrm{U}_{\mathrm{i}}(\mathrm{i}=1,2,3, \ldots, \mathrm{N})$ and $v_{i}$ are the importance of responses, thereby assessing the levels of predictor variables that produce the most desirable expected responses. (Khodadoust et al., 2013)

\subsection{Analytical Methods}

The physicochemical analysis of tiger nut, tiger nut milk and the solid residue composition obtained in the milk extraction were performed using the methods described in Official Methods of Analysis of AOAC International (1996). The parameters analyzed included: protein, carbohydrate, lipid, moisture, calcium, iron content, ascorbic acid, total sugar, reducing sugar and starch.

\section{Results and Discussion}

\subsection{Fractional Factorial Design}

The fractional factorial design was performed in order to screen the relevant variables for tiger nut milk production. The results obtained for this experimental design with its respective operating conditions are shown in Table 3. It can be observed that the yield ranged from 25.22 to $68.20 \%$, the protein concentration ranged from 0.29 to $1.49 \%$ and starch concentration varied from 2.70 to $7.50 \%$. Total sugar ranged between 1.27 and $6.25 \%$ and calcium content varied between 10.66 and $18.30 \mathrm{mg} / \mathrm{g}$. The lipid concentration ranged between 2.58 and $7.52 \%$. The center points show a small deviation for all dependent variables evaluated, with maximum average deviation of, approximately, $6 \%$. 


\section{Macrothink}

Table 3. Matrix of experimental runs for fractional factorial design

\begin{tabular}{|c|c|c|c|c|c|c|c|c|c|c|}
\hline Run & $\mathrm{X}_{1}^{*}$ & $\mathrm{X}_{2}{ }^{*}$ & $\mathrm{X}_{3} *$ & $\mathrm{X}_{4} *$ & $\begin{array}{l}\text { Protein } \\
(\%)\end{array}$ & $\begin{array}{l}\text { Calcium } \\
(\mathrm{mg} / \mathrm{g})\end{array}$ & $\begin{array}{l}\text { Lipid } \\
(\%)\end{array}$ & $\begin{array}{l}\text { starch } \\
(\%)\end{array}$ & $\begin{array}{l}\text { Total } \\
\text { sugar } \\
(\%)\end{array}$ & $\begin{array}{l}\text { Yield } \\
(\%)\end{array}$ \\
\hline 1 & -1 & -1 & -1 & -1 & $1.49 \pm 0,01$ & $10.66 \pm 0,01$ & $6.53 \pm 0,01$ & $7.50 \pm 0,04$ & $6.25 \pm 0,03$ & $67.10 \pm 0,03$ \\
\hline 2 & +1 & -1 & -1 & +1 & $0.69 \pm 0,01$ & $18.50 \pm 0,01$ & $3.46 \pm 0,04$ & $4.56 \pm 0,02$ & $2.23 \pm 0,01$ & $47.20 \pm 0,02$ \\
\hline 3 & -1 & +1 & -1 & +1 & $0.29 \pm 0,02$ & $10.70 \pm 0,01$ & $2.80 \pm 0,01$ & $2.70 \pm 0,05$ & $1.30 \pm 0,04$ & $26.00 \pm 0,05$ \\
\hline 4 & +1 & +1 & -1 & -1 & $1.19 \pm 0,01$ & $16.00 \pm 0,03$ & $7.32 \pm 0,04$ & $5.71 \pm 0,05$ & $4.49 \pm 0,01$ & $68.10 \pm 0,01$ \\
\hline 5 & -1 & -1 & +1 & +1 & $0.53 \pm 0,03$ & $10.70 \pm 0,03$ & $2.58 \pm 0,02$ & $3.52 \pm 0,05$ & $2.16 \pm 0,03$ & $25.20 \pm 0,05$ \\
\hline 6 & +1 & -1 & +1 & -1 & $1.21 \pm 0,02$ & $10.70 \pm 0,03$ & $5.97 \pm 0,02$ & $7.18 \pm 0,03$ & $4.85 \pm 0,01$ & $68.20 \pm 0,03$ \\
\hline 7 & -1 & +1 & +1 & -1 & $1.04 \pm 0,01$ & $10.70 \pm 0,01$ & $7.52 \pm 0,01$ & $5.70 \pm 0,03$ & $2.99 \pm 0,02$ & $67.15 \pm 0,04$ \\
\hline 8 & +1 & +1 & +1 & +1 & $0.34 \pm 0,02$ & $10.70 \pm 0,02$ & $2.76 \pm 0,05$ & $2.70 \pm 0,01$ & $1.27 \pm 0,02$ & $25.22 \pm 0,04$ \\
\hline 9 & 0 & 0 & 0 & 0 & $0.86 \pm 0,01$ & $16.00 \pm 0,01$ & $4.81 \pm 0,02$ & $4.60 \pm 0,02$ & $2.37 \pm 0,01$ & $55.14 \pm 0,01$ \\
\hline 10 & 0 & 0 & 0 & 0 & $0.89 \pm 0,01$ & $18.30 \pm 0,02$ & $5.27 \pm 0,02$ & $4.69 \pm 0,02$ & $2.40 \pm 0,01$ & $55.80 \pm 0,03$ \\
\hline 11 & 0 & 0 & 0 & 0 & $0.86 \pm 0,01$ & $16.00 \pm 0,01$ & $4.38 \pm 0,02$ & $4.71 \pm 0,03$ & $2.68 \pm 0,01$ & $52.60 \pm 0,02$ \\
\hline
\end{tabular}

* Coded variables Xi (i $=1,2,3,4)$ are defined in table 1. ( \pm ) standard deviation; $\mathrm{n}(11)$.

According to the Pareto diagrams (Figure 1), the only parameter that affected all the responses significantly $(\mathrm{p}<0.1)$ was water proportion $\left(\mathrm{X}_{4}\right)$ (except for calcium content), with a negative effect. 
(a)

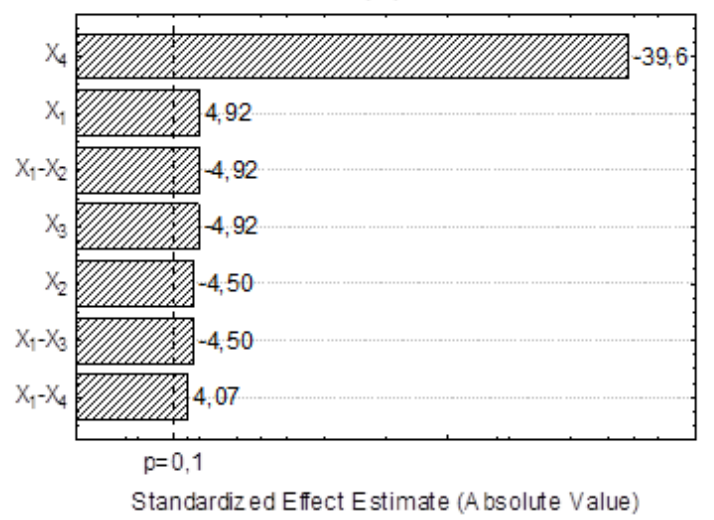

(b)

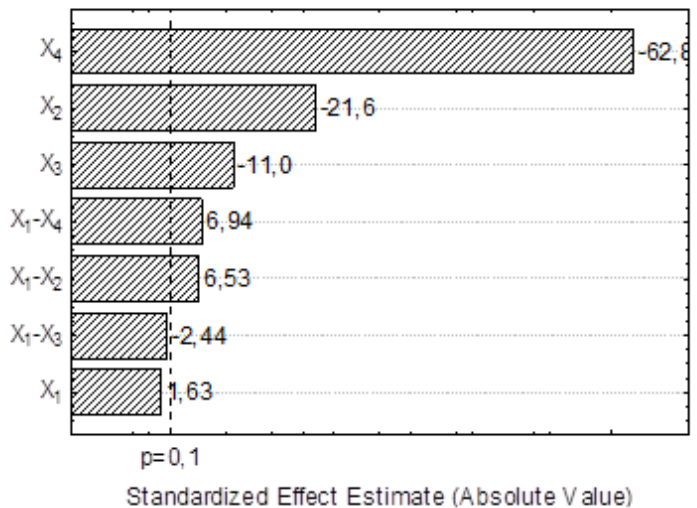

(c)

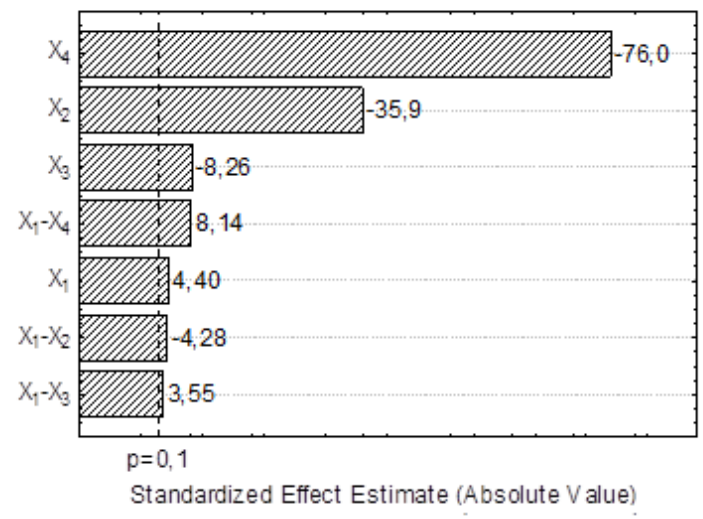

(d)

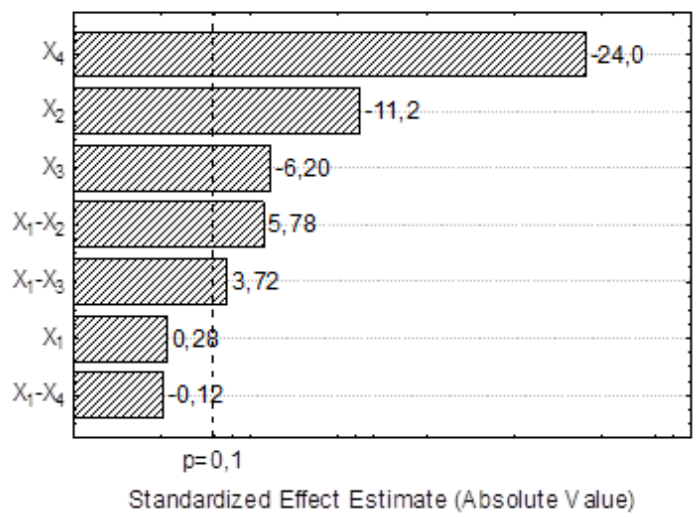

(e)

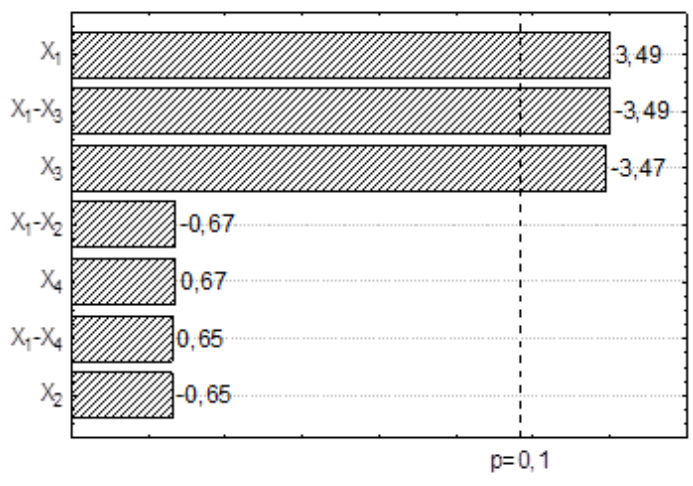

Standardized Effect Estimate (A bsolute V alue)

(f)

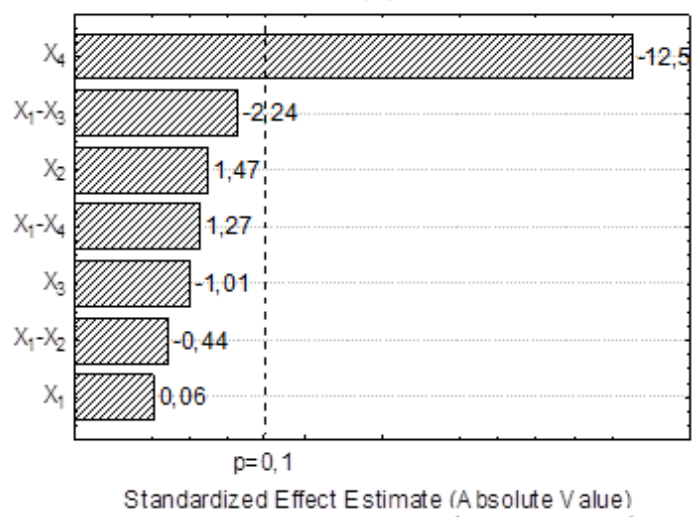

Figure 1. Pareto diagram for fractional design $2^{4-1}$ : (a) yield (\%); (b) protein (\%); (c) starch (\%); (d) total sugar (\%); (e) calcium (mg/100g) (f) lipid (\%). $\left(\mathrm{X}_{1}\right)$ Concentration of sodium metabisulphite; $\left(\mathrm{X}_{2}\right)$ Soaking Time; $\left(\mathrm{X}_{3}\right)$ Soaking temperature and $\left(\mathrm{X}_{4}\right)$ Water proportion

However, as the 1:1 water/tiger nut proportion represents the boundary extraction system under study, it was not possible to use lower proportions. Soaking temperature $\left(\mathrm{X}_{3}\right)$ and time $\left(\mathrm{X}_{2}\right)$ also affected significantly most of the response variables at $10 \%$ significance level $(\mathrm{p}$ $<0.1$ ). In this case, a positive effect was only observed for the extraction yield. For nutrient content, lower time and temperature were beneficial. Concerning sodium metabisulphite concentration $\left(\mathrm{X}_{1}\right)$, there was a tendency to higher concentrations (positive effect) when it comes to yield and tiger nut milk nutrient content. 


\subsection{Central Composite Design (CCD)}

After evaluating the results obtained via fractional design (item 3.1), it was defined that the independent variables: soaking temperature, soaking time and sodium metabisulphite concentration would be evaluated on the CCD. The variable water proportion was excluded due to experimental conditions of milk production process as explained in the previous section. The response variables used in CCD were: Yield (\%) protein (\%), starch (\%) and total sugar $(\%)$ as shown in Table 4.

Table 4. Matrix of experimental runs for the central composite designs

\begin{tabular}{llllllll}
\hline Run & $\mathrm{X}_{1}{ }^{*}$ & $\mathrm{X}_{2}{ }^{*}$ & $\mathrm{X}_{3}{ }^{*}$ & $\begin{array}{l}\text { Protein } \\
(\%)\end{array}$ & $\begin{array}{l}\text { Starch } \\
(\%)\end{array}$ & $\begin{array}{l}\text { Total sugar } \\
(\%)\end{array}$ & $\begin{array}{l}\text { Yield } \\
(\%)\end{array}$ \\
\hline 1 & -1 & -1 & -1 & $2.03 \pm 0,02$ & $7.20 \pm 0,02$ & $2.92 \pm 0,01$ & $65.70 \pm 0,05$ \\
2 & +1 & -1 & -1 & $1.89 \pm 0,01$ & $5.14 \pm 0,02$ & $3.93 \pm 0,01$ & $73.70 \pm 0,05$ \\
3 & -1 & -1 & +1 & $1.96 \pm 0,01$ & $6.45 \pm 0,01$ & $4.16 \pm 0,05$ & $76.33 \pm 0,05$ \\
4 & +1 & -1 & +1 & $1.83 \pm 0,01$ & $5.54 \pm 0,02$ & $4.38 \pm 0,04$ & $75.80 \pm 0,03$ \\
5 & -1 & +1 & -1 & $1.86 \pm 0,01$ & $4.99 \pm 0,01$ & $2.64 \pm 0,03$ & $78.00 \pm 0,01$ \\
6 & +1 & +1 & -1 & $1.97 \pm 0,04$ & $8.67 \pm 0,03$ & $4.42 \pm 0,03$ & $72.00 \pm 0,03$ \\
7 & -1 & +1 & +1 & $1.99 \pm 0,01$ & $6.31 \pm 0,01$ & $2.22 \pm 0,03$ & $76.00 \pm 0,01$ \\
8 & +1 & +1 & +1 & $1.75 \pm 0,01$ & $4.67 \pm 0,04$ & $3.87 \pm 0,01$ & $69.00 \pm 0,02$ \\
9 & 0 & -1.68 & 0 & $2.01 \pm 0,01$ & $7.58 \pm 0,01$ & $3.96 \pm 0,02$ & $77.00 \pm 0,02$ \\
10 & 0 & +1.68 & 0 & $1.88 \pm 0,01$ & $7.78 \pm 0,01$ & $2.77 \pm 0,01$ & $75.00 \pm 0,02$ \\
11 & 0 & 0 & -1.68 & $2.13 \pm 0,03$ & $6.96 \pm 0,05$ & $2.22 \pm 0,02$ & $73.20 \pm 0,04$ \\
12 & 0 & 0 & +1.68 & $1.96 \pm 0,01$ & $7.39 \pm 0,02$ & $4.26 \pm 0,02$ & $78.10 \pm 0,04$ \\
13 & -1.68 & 0 & 0 & $1.69 \pm 0,02$ & $6.20 \pm 0,01$ & $1.57 \pm 0,02$ & $73.00 \pm 0,03$ \\
14 & +1.68 & 0 & 0 & $1.65 \pm 0,02$ & $4.99 \pm 0,02$ & $6.11 \pm 0,05$ & $72.00 \pm 0,02$ \\
15 & 0 & 0 & 0 & $1.44 \pm 0,01$ & $5.10 \pm 0,02$ & $2.74 \pm 0,03$ & $67.00 \pm 0,02$ \\
16 & 0 & 0 & 0 & $1.54 \pm 0,01$ & $4.90 \pm 0,02$ & $1.49 \pm 0,03$ & $71.00 \pm 0,01$ \\
17 & 0 & 0 & 0 & $1.10 \pm 0,01$ & $5.80 \pm 0,02$ & $2.03 \pm 0,02$ & $69.00 \pm 0,01$ \\
\hline$*$ & & & & & & &
\end{tabular}

* Coded variables Xi $(i=1,2,3,4)$ are defined in table 1. ( \pm ) standard deviation; n. (17).

The yield response ranged from $65.70 \%$ to $78.10 \%$, protein concentration from $1.10 \%$ to $2.13 \%$ and starch concentration from $4.67 \%$ to $8.67 \%$ (Tab.4). For those parameters there was a significant increase $(\mathrm{p}<0.05)$ as compared to the values obtained in the fractional design (Table 3 ). For the total sugar concentration that ranged from $1.49 \%$ to $6.11 \%$ (Table 4 ), the results were similar to the previous ones obtained in fractional design (Table 3$)(p>0.05)$.

The analysis of variance (ANOVA) was carried out for all response variables to optimize the 
tiger nut milk manufacturing process, and consequently determine a fitted predictive model $(\mathrm{p}<0.1)$ as shown in Table 5 .

Table 5. Analysis of variance (ANOVA) for central composite design for yield, protein, total sugar and starch

\begin{tabular}{|c|c|c|c|c|c|}
\hline Factor* & $\begin{array}{l}\text { Sum of } \\
\text { square }\end{array}$ & $\mathbf{D F}^{\mathbf{a}}$ & $\begin{array}{l}\text { Mean } \\
\text { square }\end{array}$ & F-value ${ }^{b}$ & Pvalue \\
\hline \multicolumn{6}{|c|}{ Yield $(\%) ; R^{2}=0.8651$} \\
\hline $1-\mathrm{X}_{2}(\mathrm{~L})$ & 0.0523 & 1 & 0.05235 & 0.05235 & 0.919370 \\
\hline $\mathrm{X}_{2}(\mathrm{Q})$ & 49.2326 & 1 & 49.23261 & 49.23261 & 0.072520 \\
\hline $2-X_{3}(L)$ & 17.6082 & 1 & 17.60823 & 17.60823 & 0.170783 \\
\hline $\mathrm{X}_{3}(\mathrm{Q})$ & 43.5742 & 1 & 43.57424 & 43.57424 & 0.080824 \\
\hline $3-X_{1}(L)$ & 3.5225 & 1 & 3.52255 & 3.52255 & 0.447090 \\
\hline $\mathrm{X}_{1}$ & 7.9624 & 1 & 7.96238 & 7.96238 & 0.293727 \\
\hline $\mathrm{X}_{1} \mathrm{~L}-\mathrm{X}_{2} \mathrm{~L}$ & 39.2941 & 1 & 39.29411 & 39.29411 & 0.088493 \\
\hline $\mathrm{X}_{1} \mathrm{~L}-\mathrm{X}_{3} \mathrm{~L}$ & 51.1274 & 1 & 51.12736 & 51.12736 & 0.070108 \\
\hline $\mathrm{X}_{2} \mathrm{~L}-\mathrm{X}_{3} \mathrm{~L}$ & 11.5909 & 1 & 11.59092 & 11.59092 & 0.230814 \\
\hline Lack of fit & 22.5786 & 5 & 4.51571 & 4.51571 & 0.531513 \\
\hline Pure error & 8.0000 & 2 & 4.00000 & & \\
\hline Total SS & 226.7184 & 16 & & & \\
\hline \multicolumn{6}{|c|}{ Protein $(\%) ; R^{2}=0.8730$} \\
\hline $1-\mathrm{X}_{2}(\mathrm{~L})$ & 0.009052 & 1 & 0.009052 & 0.17015 & 0.719992 \\
\hline $\mathrm{X}_{2}(\mathrm{Q})$ & 0.473094 & 1 & 0.473094 & 8.89275 & 0.096456 \\
\hline $2-X_{3}(L)$ & 0.019901 & 1 & 0.019901 & 0.37407 & 0.603055 \\
\hline $\mathrm{X}_{3}(\mathrm{Q})$ & 0.650503 & 1 & 0.650503 & 12.22750 & 0.072947 \\
\hline $3-\mathrm{X}_{1}(\mathrm{~L})$ & 0.011022 & 1 & 0.011022 & 0.20719 & 0.693618 \\
\hline $\mathrm{X}_{1}(\mathrm{Q})$ & 0.127666 & 1 & 0.127666 & 2.39974 & 0.261469 \\
\hline $\mathrm{X}_{2} \mathrm{~L}-\mathrm{X}_{3} \mathrm{~L}$ & 0.000200 & 1 & 0.000200 & 0.00376 & 0.956685 \\
\hline $\mathrm{X}_{2} \mathrm{~L}-\mathrm{X}_{1} \mathrm{~L}$ & 0.002611 & 1 & 0.002611 & 0.04909 & 0.845224 \\
\hline $\mathrm{X}_{3} \mathrm{~L}-\mathrm{X}_{1} \mathrm{~L}$ & 0.013995 & 1 & 0.013995 & 0.26306 & 0.659059 \\
\hline Lack of fit & 0.028958 & 5 & 0.005792 & 0.10887 & 0.978830 \\
\hline Pure error & 0.106400 & 2 & 0.053200 & & \\
\hline Total SS & 1.065024 & 16 & & & \\
\hline
\end{tabular}

Total sugar $(\%) ; \mathbf{R}^{2}=\mathbf{0 . 8 3 3 1}$ 


\begin{tabular}{|c|c|c|c|c|c|}
\hline $1-\mathrm{X}_{2}(\mathrm{~L})$ & 1.25160 & 1 & 1.25160 & 3.18447 & 0.216270 \\
\hline $\mathrm{X}_{2}(\mathrm{Q})$ & 2.07747 & 1 & 2.07747 & 5.28572 & 0.148243 \\
\hline $2-X_{3}(L)$ & 1.23061 & 1 & 1.23061 & 3.13105 & 0.218837 \\
\hline $\mathrm{X}_{3}(\mathrm{Q})$ & 1.67170 & 1 & 1.67170 & 4.25333 & 0.175276 \\
\hline $3-\mathrm{X}_{1}(\mathrm{~L})$ & 11.83782 & 1 & 11.83782 & 30.11911 & 0.031634 \\
\hline $\mathrm{X}_{1}(\mathrm{Q})$ & 3.73029 & 1 & 3.73029 & 9.49104 & 0.091181 \\
\hline $\mathrm{X}_{2} \mathrm{~L}-\mathrm{X}_{3} \mathrm{~L}$ & 0.88445 & 1 & 0.88445 & 2.25032 & 0.272369 \\
\hline $\mathrm{X}_{2} \mathrm{~L}-\mathrm{X}_{1} \mathrm{~L}$ & 0.61287 & 1 & 0.61287 & 1.55933 & 0.338111 \\
\hline $\mathrm{X}_{3} \mathrm{~L}-\mathrm{X}_{1} \mathrm{~L}$ & 0.13342 & 1 & 0.13342 & 0.33948 & 0.619070 \\
\hline Lack of fit & 3.30334 & 5 & 0.66067 & 1.68095 & 0.413548 \\
\hline Pure error & 0.78607 & 2 & 0.39303 & & \\
\hline Total SS & 24.51481 & 16 & & & \\
\hline \multicolumn{6}{|c|}{ Starch; $R^{2}=0.6355$} \\
\hline $1-\mathrm{X}_{2}(\mathrm{~L})$ & 0.05687 & 1 & 0.056873 & 0.25466 & 0.663925 \\
\hline $\mathrm{X}_{2}(\mathrm{Q})$ & 5.28000 & 1 & 5.280001 & 23.64180 & 0.039790 \\
\hline $2-\mathrm{X}_{3}(\mathrm{~L})$ & 0.46010 & 1 & 0.460095 & 2.06013 & 0.287677 \\
\hline $\mathrm{X}_{3}(\mathrm{Q})$ & 2.88420 & 1 & 2.884202 & 12.91434 & 0.069462 \\
\hline $3-\mathrm{X}_{1}(\mathrm{~L})$ & 0.73308 & 1 & 0.733082 & 3.28246 & 0.211718 \\
\hline $\mathrm{X}_{1}(\mathrm{Q})$ & 0.02380 & 1 & 0.023800 & 0.10657 & 0.775081 \\
\hline $\mathrm{X}_{2} \mathrm{~L}-\mathrm{X}_{3} \mathrm{~L}$ & 0.67861 & 1 & 0.678612 & 3.03856 & 0.223430 \\
\hline $\mathrm{X}_{2} \mathrm{~L}-\mathrm{X}_{1} \mathrm{~L}$ & 3.12603 & 1 & 3.126030 & 13.99715 & 0.064598 \\
\hline $\mathrm{X}_{3} \mathrm{~L}-\mathrm{X}_{1} \mathrm{~L}$ & 2.28764 & 1 & 2.287636 & 10.24314 & 0.085318 \\
\hline Lack of fit & 8.10197 & 5 & 1.620393 & 7.25549 & 0.125551 \\
\hline Pure error & 0.44667 & 2 & 0.223333 & & \\
\hline Total SS & 23.45401 & 16 & & & \\
\hline
\end{tabular}

*Concentration of sodium metabisulphite $\left(\mathrm{X}_{1}\right)$; Soaking Time $\left(\mathrm{X}_{2}\right)$; Soaking temperature $\left(\mathrm{X}_{3}\right)$; ${ }^{a} \mathrm{DF}$ : degrees of freedom; ${ }^{\mathrm{b}}$ Test for comparing model variance with residual (error) variance.

It can be seen from table 5 that the quadratic $\left(\mathrm{X}_{2}{ }^{2}, \mathrm{X}_{3}{ }^{2}\right)$ and interaction terms $\left(\mathrm{X}_{1} \cdot \mathrm{X}_{2}, \mathrm{X}_{1} \cdot \mathrm{X}_{3}\right)$ for yield and starch concentration were statistically significant due to the small $\mathrm{p}$-values $(p<$ $0,1)$. For the protein concentration only quadratic terms $\left(\mathrm{X}_{2}^{2}, \mathrm{X}_{3}{ }^{2}\right)$ were statistically significant and for the total sugar concentration just the linear term $\left(\mathrm{X}_{1}\right)$ and quadratic term $\left(\mathrm{X}_{1}{ }^{2}\right)$ were statistically significant. The results of the analysis of variance (ANOVA) of yield response, protein concentration, total sugar concentration and starch concentration reveal high contribution of the quadratic model for the explanation of the tiger nut milk extraction 


\section{Macrothink

performance (significant with $p<0,1$ ). The lack of fit (LOF) as a symbol of data variation around the fitted model is criterion for judgment about adequacy of a model for fitting the experimental result. The significant of LOF shows the non-suitability of models for well-fitting the experimental data. A p-value of LOF to yield response was 0.531 , for protein concentration was 0.978 , for total sugar concentration was 0.413 and for starch was 0.125 . These values of LOF indicate the good ability of models and best selection of optimum conditions to tiger nut milk extraction.

The suitability of the polynomial model equations were expressed by the coefficient of determination $\left(R^{2}\right)$, which their value reveals the amount of deviation around the mean. The $R^{2}$ for the yield was 0.865 , for protein concentration was 0.873 , for total sugar concentration was 0.833 and for starch concentration was 0.635 . The high adjusted $R^{2}$ values indicate a good correlation and relationship between the experimental data and the obtained model. Applying multiple regression analysis on the experimental data, the quadratic polynomial models for the predicated yield (Y\%), Protein concentration (P\%), Total sugar concentration (TS\%) and Starch concentration ( $\mathrm{S} \%$ ) were shown as follows, respectively (in the form of real values):

$$
\begin{aligned}
& Y(\%)=+90.67+0.52\left(X_{2}\right)^{2}+0.078\left(X_{3}\right)^{2}-0.22 X_{2} \cdot X_{3}-11.22 X_{2} \cdot X_{1} \\
& P \%=12.26+0.051\left(X_{2}\right)^{2}-0.57 . X_{3}+0.009\left(X_{3}\right) \\
& T S \%=13.17-9.21 X_{1}+45.34\left(X_{1}\right)^{2} \\
& S(\%)=23.36+0.171\left(X_{2}\right)^{2}+0.020\left(X_{3}\right)^{2}+2.77 X_{2} . X_{1}-0.95 X_{3} . X_{1}
\end{aligned}
$$

Figure 2 shows the most relevant fitted response surfaces for the design and depicts the response surface plots of yield response, protein concentration, total sugar concentration and starch concentration versus significant variables. 


\section{MInstitute ${ }^{\text {Mink }}$}

(a)

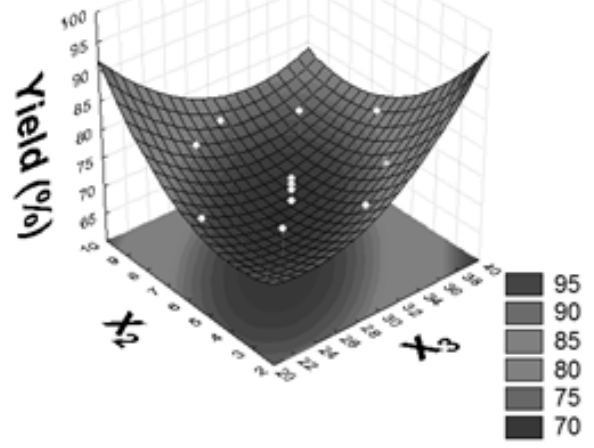

(b)

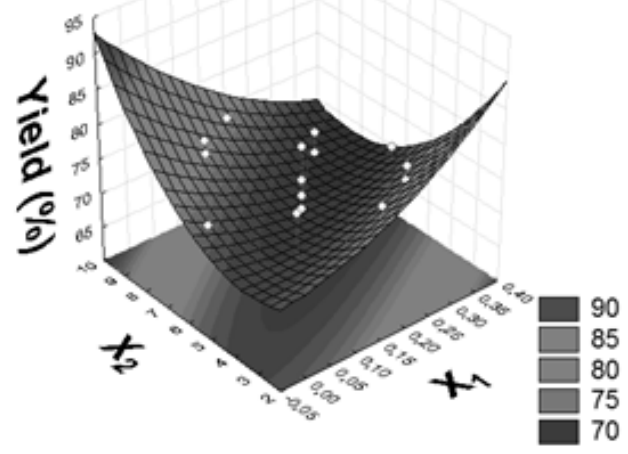

(c)

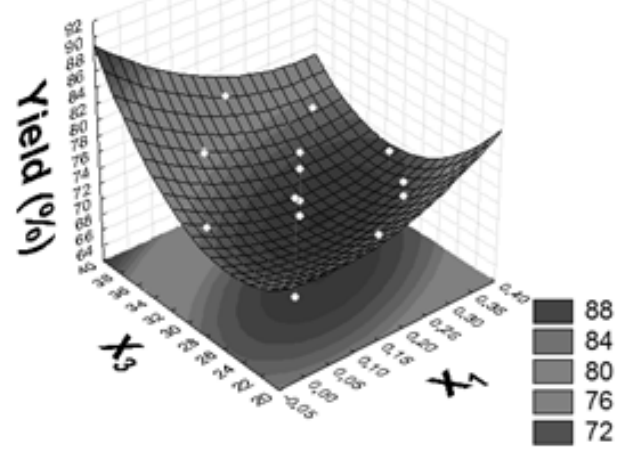

(d)

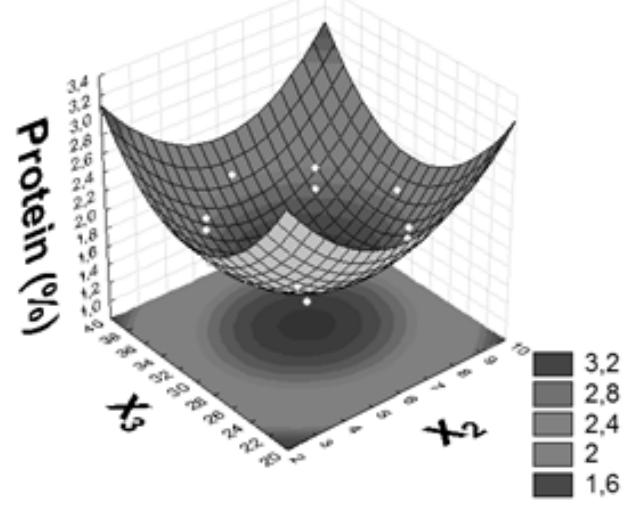

Journal of Food Studies

ISSN 2166-1073 2017, Vol. 6, No. 1 (e)

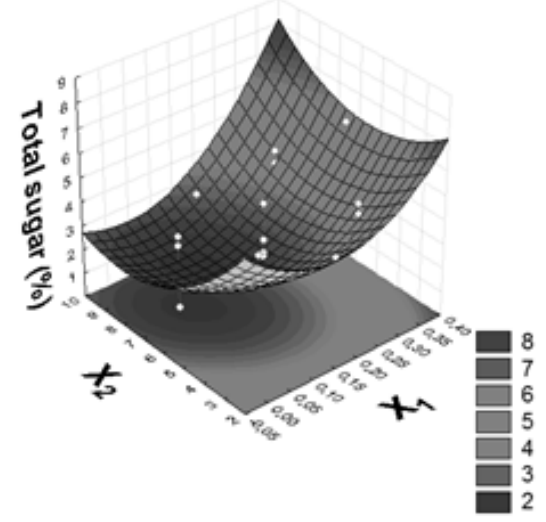

(f)

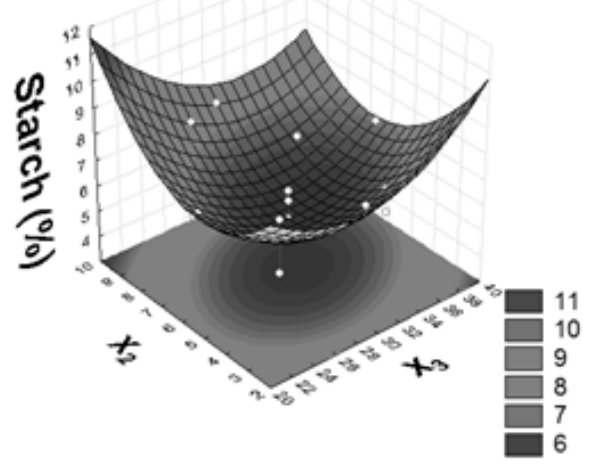

(g)

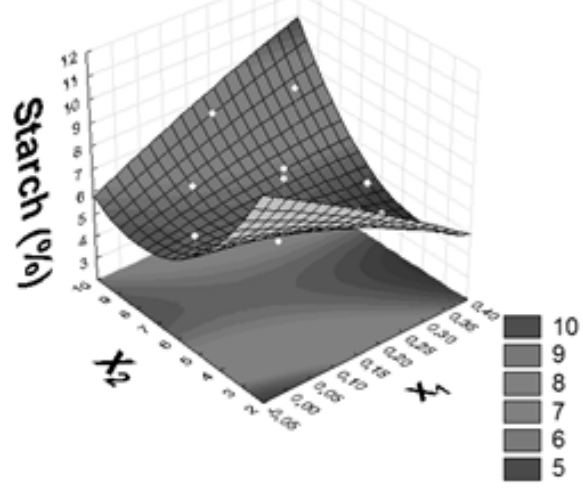

(h)

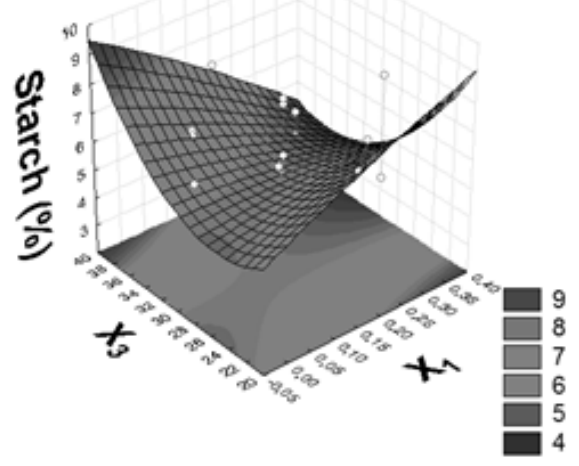




\section{Macrothink

Figure 2. Response surfaces for tiger nut milk production for response variables: Yield (\%), protein (\%), total sugar (\%) and starch (\%). (a) $X_{3}-X_{2}$ (yield); (b) $X_{1}-X_{2}$ (yield); (c) $X_{1}-$ $\mathrm{X}_{3}$ (yield); (d) $\mathrm{X}_{2}-\mathrm{X}_{3}$ (protein); (e) $\mathrm{X}_{1}-\mathrm{X}_{2}$ (total sugar); (f) $\mathrm{X}_{3}-\mathrm{X}_{2}$ (starch); (g) $\mathrm{X}_{1}-\mathrm{X}_{2}$ (starch); (h) $\mathrm{X}_{1}-\mathrm{X}_{3}$ (starch)

The curvatures of these plots confirm the presence of their interaction. For the yield the surface plot shows that the increased yield $(\mathrm{Y} \%)$ is due to the increased soaking time $\left(\mathrm{X}_{2}\right)$ and soaking temperature $\left(\mathrm{X}_{3}\right)$ (Figure 2), since the increase of both variables allows the tuber tiger nut to absorb larger amount of water that directly affects the ability to produce more milk. Consequently higher yields are obtained with maximum saturation of $12 \mathrm{~h}$ and $60{ }^{\circ} \mathrm{C}$. However, under these conditions, milk gelatinizes $\left(>60^{\circ} \mathrm{C}\right)$ and becomes darker $(>12 \mathrm{pm})$ with sensory conditions probably impaired due to the action of proteases, amylases and lipases (Peleg, 1988; Ejoh et al., 2006). In contrast, the linear interactions soaking time-soaking temperature and soaking time decrease the yield of the tiger nut milk production process (Figure 2).

For protein concentrations the surface plot shows a similar behavior to the yield response. For total sugar concentration the surface plots depicts that the minimum total sugar occurs at lower concentrations of sodium metabisulphite $\left(\mathrm{X}_{1}\right)$ and higher soaking time $\left(\mathrm{X}_{2}\right)$. For the increased starch content quadratic terms of soaking time $\left(\mathrm{X}_{2}\right)$ and soaking temperature increases $\left(\mathrm{X}_{3}\right)$ (Figure 2). In contrast, linear interaction between the soaking temperature and the sodium metabisulphite concentration adversely affected this response variable.

\subsection{Optimization of Central Composite Design}

The desirability aims at optimizing processes with more than one dependent variable, where there is a number range that defines the analyst's desirability in relation to the optimum condition of the process. Optimizing the central composite design via desirability function showed that the optimum conditions of the independent variables of this study to obtain the maximum responses of yield, protein and starch was achieved at $9 \mathrm{~h}$ of soaking time, $25^{\circ} \mathrm{C}$ of soaking temperature and $0.21 \%$ sodium metabisulpite concentration (Figure 3 ). 


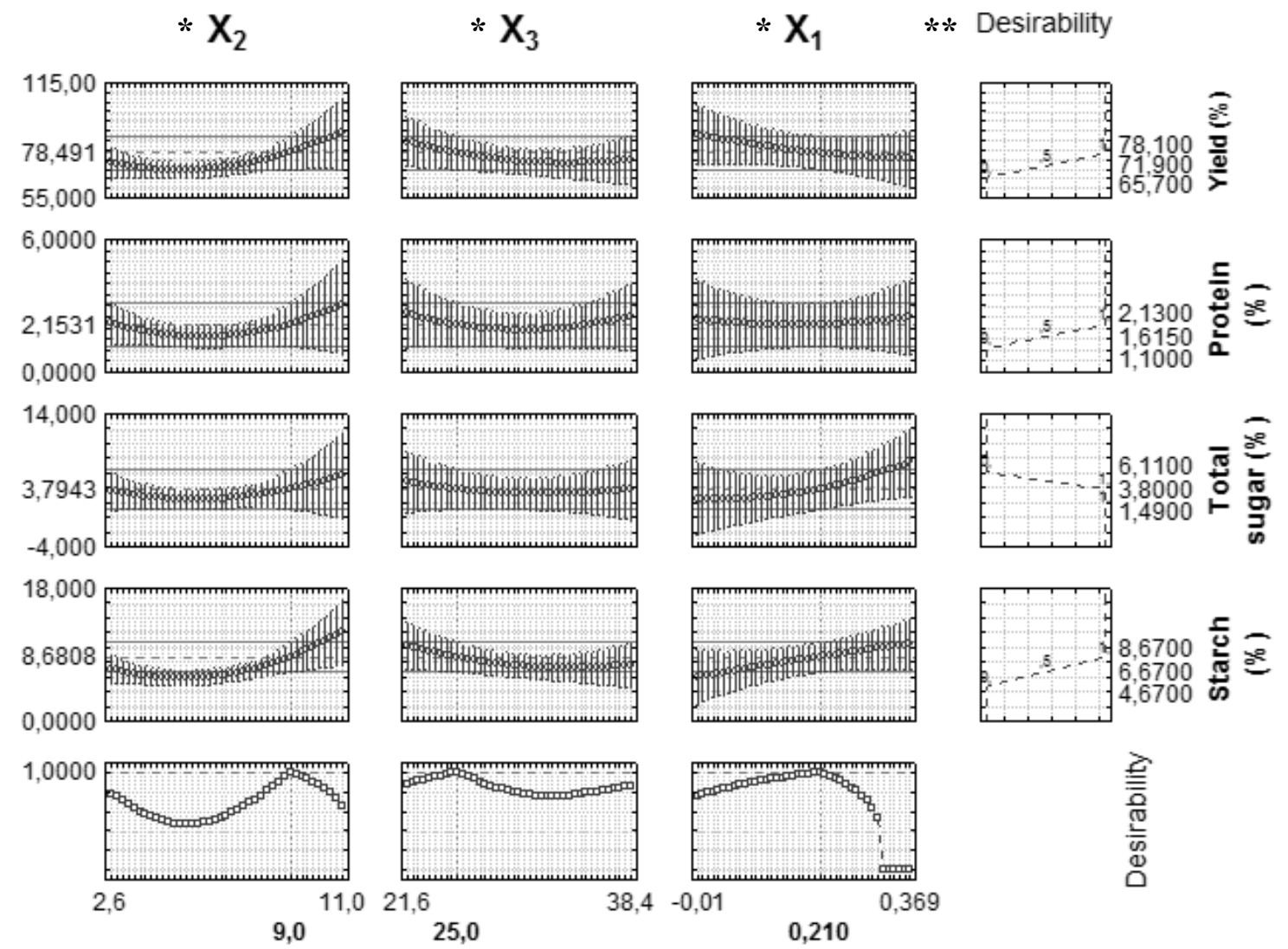

Figure 3. Profiles for predicated values and desirability function for yield, protein, starch and total sugar. Dashed line indicates current values after optimization

*Sodium metabisulphite $\left(\mathrm{X}_{1}\right)$; Soaking time $\left(\mathrm{X}_{2}\right)$; Soaking temperature $\left(\mathrm{X}_{3}\right)$; **Desireability equal to 1.0 corresponds maximum value; Desireability equal to 0.5 corresponds intermediate value; Desireability equal to 0.0 corresponds minimum value.

The desired response for the total sugar variable via desireability function corresponds to intermediate values, since higher values of total sugar in milk may represent a possible decrease in starch content during storage, a fact that influences decisively in its sensory quality as noted by Sanches-Zapatta et al. (2012).

3.4 Centesimal Analysis of Tiger Nut, Tiger Nut "Milk" and Solid Waste (SW) from the Tiger Nut Milk Extraction

After setting the best operating conditions for the production of tiger nut milk, compositional analysis was performed thereof, as well as the analysis of the solid waste (SW) formed during its production. Table 6 shows the results including the analysis of the starting material before milk production (tiger nut). 
Table 6. Chemical composition of tiger nut, tiger nut milk and solid waste

\begin{tabular}{llll}
\hline Compounds $(\%)$ & Tiger nut & Tiger nut milk & Solid waste \\
\hline Starch & $23.8 \pm 0.03$ & $8.72 \pm 0.02$ & $11.9 \pm 0.01$ \\
reducing sugar & $9.80 \pm 0.02$ & $3.30 \pm 0.01$ & $2.70 \pm 0.02$ \\
Total sugar & $12.1 \pm 0.03$ & $3.70 \pm 0.04$ & $4.87 \pm 0.01$ \\
Moisture & $33.5 \pm 0.02$ & $82.1 \pm 0.03$ & $67.1 \pm 0.04$ \\
Ash & $1.03 \pm 0.01$ & $0.22 \pm 0.04$ & $0.56 \pm 0.03$ \\
Lipid & $15.7 \pm 0.01$ & $8.39 \pm 0.01$ & $7.26 \pm 0.03$ \\
Protein & $6.30 \pm 0.01$ & $2.60 \pm 0.03$ & $3.05 \pm 0.01$ \\
Total carbohydrate & $46.5 \pm 0.02$ & $7.61 \pm 0.03$ & $22.1 \pm 0.03$ \\
iron $*$ & $4.25 \pm 0.01$ & $1.88 \pm 0.01$ & $3.10 \pm 0.01$ \\
calcium * & $53.5 \pm 0.02$ & $42.5 \pm 0.02$ & $10.4 \pm 0.03$ \\
Vitamin C $*$ & $4.51 \pm 0.02$ & $1.76 \pm 0.01$ & $2.63 \pm 0.02$ \\
\hline
\end{tabular}

* Values expressed in mg/100g. ( \pm ) standard deviation; $\mathrm{n}(5)$.

Table 6 shows that those compounds that prevails in the tiger nut milk were starch $(8.72 \%)$, lipids (8.39\%), carbohydrate (7.61\%) and total sugar (3.70\%). Some authors obtained lower values for lipids $(3.09 \%)$ (Alégria-Toran \& Farré-Rovira, 2003). In addition, the result for protein $(2.60 \pm 0.03)$ was quite significant, exceeding those obtained by Alégria-Toran and Farré-Rovira. (2003) (approximately $0.91 \%$ of protein). Regarding other compounds, it is important to emphasize the vitamin C content of $1.76 \mathrm{mg} / 100 \mathrm{~g}$ even after possible losses during the extraction process. The calcium content was, approximately, 4 times higher (45.5 $\mathrm{mg} / 100 \mathrm{~g}$ ) as compared with the first results obtained in this study (Tab.3) and significant iron concentration were also achieved $(1.88 \mathrm{mg} / 100 \mathrm{~g})$.

Therefore, the optimization study for milk production via sequential design of experiments influenced considerably in milk's nutritional characteristics.

As for the compounds analyzed in the initial raw material (tiger nut) (Table 6), those in greater quantity were: starch $(23.8 \%)$, carbohydrate $(46.54 \%)$ and lipid $(15.70 \%)$; results similar to those found by Mokaday et al. (1970) and Hayford et al. (2015). It shows that much of those compounds are not extracted by the process of milk production. As a result, the nutrient content found in the solid waste (Table 6) was significant, even after optimizing the tiger nut milk production procedure. Therefore, this solid waste can be used in a complementary manner in the food industry, since in addition to having higher protein levels when compared to the results obtained by Sanchez-Zapatta et al. (2009) (approximately $1.75 \%)$ it showed significant contents of vitamin C (2.63 mg / 100g), iron (3.1 mg / $100 \mathrm{~g})$ and calcium $(10.45 \mathrm{mg} / 100 \mathrm{~g})$.

\section{Conclusion}

Sodium metabisulphite, soaking time and temperature and water proportion influences 


\section{MInstitute ${ }^{\text {Macrothink }}$}

significantly tiger nut milk extraction process. The best operational conditions for yield and nutritional value of this drink is: 8 hours of soaking time, $22{ }^{\circ} \mathrm{C}$ soaking temperature, $0.20 \%$ sodium metabisulphite concentration and 1:1 water proportion. The high yield obtained $(78.10 \%)$ and the great nutritional value $(42.5 \mathrm{mg} / 100 \mathrm{~g}$ calcium content, $2.60 \%$ of protein, $1.76 \mathrm{mg} / 100 \mathrm{~g}$ vitamin C, 3.30\% reducing sugar, 3.70\% total sugar, $82.18 \%$ moisture, $0.22 \%$ ash, $8.39 \%$ lipids, $7.61 \%$ total carbohydrate, $1.88 \mathrm{mg} / 100 \mathrm{~g}$ iron and $8.76 \%$ starch) shows that this milk has a great potential for application in the food industry.

The solid waste generated still retains good nutritional value and, therefore, it is quite promising for complementary uses in the food industry.

\section{References}

Alegría-Torán, A., \& Farré-Rovira, R. (2003). Horchata y salud: Aspectos nutricionales y dietéticos. In: Fundación Valenciana de Estudios Avanzados, editor. Jornada Chufa y Horchata: Tradición y Salud. Valencia, Spain: Consellería de Agricultura, Pesca y Alimentación. 55-70.

AOAC. (1996). Official methods of analysis. Association Of Analytical Chemists. Washington, DC.

Assante, F. A., Saalia, F. K., Oduro, I., \& Ellis, W. O. (2014). Modelling of milk solids extration from tigernut (Cyperus esculentus L) tubers using response Surface methodology. International Journal of Food Science an Nutrition Engineering, 3, 73-79.

Corrales, M., Souza, P. M., Stahl, M. R., \& Fernández, A. (2012). Effects of the decontamination of a fresh tiger nut's milk beverage (horchata) with short wave ultraviolet treatments (UV-C) on quality attributes. Innovative Food Science and Emerging Technologies, 13, 163-168. https://doi.org/10.1016/j.ifset.2011.07.015

Cortés, C., Esteve, M. J., Frígola, A., \& Torregrosa, F. (2004). Physical and chemical properties of different commercially available types of "horchata de chufa". Italian Journal of Food Science, 1, 113-121.

Cortés, C., Esteve. M. J., Frígola, A., \& Torregrosa, F. (2005). Qualit characteristics of horchata (a Spanish vegetable beverage) treated with pulsed electric fields during shelf-life. Food chemistry, 91, 319-325. https://doi.org/10.1016/j.foodchem.2004.06.014

Djomdi, R., Ejoh, \& Ndjouenkeu, R. (2007). Soaking behaviour and milk extraction performance of tiger nut (Cyperus esculentus) tubers. Journal of food engineering, 78, 546-550. https://doi.org/10.1016/j.jfoodeng.2005.10.022

Ejoh, R. A., Djomdi, R., \& Ndjouenkeu, R. (2006). Characteristics of tigernut (Cyperus esculentus) tubers and their performance in the production of a milk drink. Journal of Food Processing and preservation, 30, 145-163. https://doi.org/10.1111/j.1745-4549.2006.00056.x

Ghaedi, M., Mazaheri, H., Khodadoust, S., Hajati, S., \& Purkait, M. K. (2015). Application of central composite design for simultaneous removal of methylene blue and $\mathrm{Pb}^{2+}$ ion by walnut wood activated carbon. Spectrochimica Acta Part A: Molecular and Biomolecular Spectroscopy, 135, 479-490. https://doi.org/10.1016/j.saa.2014.06.138

Hayford, N. K., Jaros, D., Schneider, Y., \& Rohm, H. (2015). Characteristics of tiger nut milk: effects of milling. International Journal of Food Science and Technology, 50, 381-388. 


\section{Macrothink}

https://doi.org/10.1111/ijfs.12649

Khodadoust, S., \& Ghaedi, M. (2013). Optimization of dispersive liquid-liquid microextraction with central composite design for preconcentration of chlordiazepoxide drug and its determination by HPLC-UV. Journal of Separation Science, 36, 1734-1742. https://doi.org/10.1002/jssc.201300085

Krokida, M. K., \& Marinos-kouris, D. (2003). Rehydration kinetics of dehydrated products. Journal of Food Engineering, 57, 1-7. https://doi.org/10.1016/S0260-8774(02)00214-5

Mokady, S. H, \& Dolev, A. (1970). Nutritional evaluation of tubers of Cyperus esculentus L. J. Sci Food Agric, 21, 211-214. https://doi.org/10.1002/jsfa.2740210411

Oliveira, L. F, Ferraz, L. R. F., \& Teixeira, L. V. (2006). Avaliação da qualidade nutricional do tubérculo e do extrato vegetal "leite" da junça (Cyperus esculentus). Universidade Federal do Maranhão.

Pascual, B, Maroto, J. V, Lopez-Galarza, S, Sanbautista, A, \& Alagarda, J. (2000). Chufa (Cyperus esculentus L. var. sativus Boeck.): An unconventional crop. Studies related to applications and cultivation. Economic Botany, 4, 439-448. https://doi.org/10.1007/BF02866543

Peleg, M. (1988). An empirical model for the description of moisture sorption curves. Journal of Food Science, 4, 1216-1219. https://doi.org/10.1111/j.1365-2621.1988.tb13565.x

Salem, M. L, Zommara, M., \& Imaizum, K. (2005). Dietary supplementation with Cyperus esculentus L. (tiger nut) tubers attenuated atherosclerotic lesion in apolipoprotein and knockout mouse associated with inhibition of inflammatory all responses. American journal of immunology, 1, 60-67. https://doi.org/10.3844/ajisp.2005.60.67

Sanchez-Zapatta, E, Fuentes-zaragoza, E., Fernadez-lopez, J., Sendra, E., Sayas, E., Navarro, C., \& Perez alvarez, J. A. (2009) Preparation of dietary fiber poder from tiger nut (Cyperus esculentus) milk ("Horchata") byproducts and its physicochemical properties. J. Agr. Food Chem, 57, 7719-7725. https://doi.org/10.1021/jf901687r

Sanchez-Zapatta, E., López, J. F., \& Alvarez, J. A. P. (2012). Tiger nut (Cyperus esculentus) Commercialization; Health Apects, Composition, Properties, and Food Aplications. Food Science and Food Safety, 11, 366-377. https://doi.org/10.1111/j.1541-4337.2012.00190.x

Shaker, M. A., Ahmed, M. G., Amany, M. B., \& Shereen, L. N. (2009). Chufa tubers (Cyperus esculentus L): As a New Source of Food. World Appl. Sci. J, 2, 151-156.

\section{Copyright Disclaimer}

Copyright for this article is retained by the author(s), with first publication rights granted to the journal.

This is an open-access article distributed under the terms and conditions of the Creative Commons Attribution license (http://creativecommons.org/licenses/by/3.0/). 